PERM JOURNAL OF PETROLEUM AND MINING ENGINEERING

ВЕСТНИК ПНИПУ. ГЕОЛОГИЯ. НЕФТЕТАЗОВОЕ И ГОРНОЕ ДЕЛО

ISSN 2224-9923

Volume/ Toм 19 №4, 2019

http://vestnik.pstu.ru/geo/

UDC 622.276+622.323.023.43:553.982.2

Review / Обзор

(c) PNRPU / ПНИПУ, 2019

\title{
USING CARBON DIOXIDE TO DEVELOP HIGHLY VISCOUS OIL FIELDS IN CARBONATE RESERVOIRS. GLOBAL EXPERIENCE ANALYSIS
}

\section{S.A. Kalinin, O.A. Morozyuk}

PermNIPIneft branch of LUKOIL-Engineering LLC in Perm (3a Permskaya st., Perm, 614066, Russian Federation)

\section{РАЗРАБОТКА МЕСТОРОЖДЕНИЙ ВЫСОКОВЯЗКОЙ НЕФТИ В КАРБОНАТНЫХ КОЛЛЕКТОРАХ С ИСПОЛЬЗОВАНИЕМ ДИОКСИДА УГЛЕРОДА. АНАЛИЗ МИРОВОГО ОПЫТА}

\section{С.А. Калинин, О.А. Морозюк}

Филиал ООО «ЛУКОЙЛ-Инжиниринг “ПермНИПИнефть”» в г. Перми (614066, Россия, г. Пермь, ул. Пермская, 3а)

Received / Получена: 05.07.2019. Accepted / Принята: 01.11.2019. Published / Опубликована: 27.12.2019

Key words:

highly viscous oil, carbonate reservoir, enhanced oil recovery, carbon dioxide, Permo-

Carboniferous deposit of Usinskoe field, immiscible displacement, simulation technology.

\begin{abstract}
The problem of intensifying the development of vast highly viscous oil resources is becoming increasingly important, urging oil and gas producers to implement state-of-the-art technologies. The conventional methods used in highly viscous oil production cannot provide a recovery factor better than 15-20\%. Therefore, the key challenge in solving this problem is to select and implement effective technologies enabling the production of such hydrocarbon resources.

Some of the current technologies are based on using carbon dioxide as a stimulation agent. These technologies are successfully applied in highly viscous oil fields around the world.

This paper reviews and analyses the performance of projects for carbon dioxide injection at highly viscous oil deposits in carbonate reservoirs. It provides information concerning the results of the implementation of the projects for carbon dioxide injection in the domestic and foreign fields.

The project performance analysis was based on such indicators as the ratio of injected gas to produced oil volume, the increment of oil recovery factor and the oil production rate per one well.

The analysis shows that the ratio of injected carbon dioxide to produced oil volume can vastly vary depending on the geological and physical characteristics of the deposits. Along with that, cyclic $\mathrm{CO}_{2}$ injection requires lesser quantities of the gas compared to dispersed injection. An increment of the oil recovery factor can reach $9.14 \%$ at highly viscous oil production rate growth up to $3.8 \mathrm{~m}^{3} /$ day/well on average.
\end{abstract}

Все большую актуальность приобретает проблема вовлечения в более активную разработку огромных ресурсов высоковязкой нефти, что требует от нефтегазодобывающих компаний внедрения современных технологий. Применение традиционных методов добычи высоковязкой нефти не позволяет достичь коэффициента извлечения выше 15-20\%. Таким образом, ключевым вопросом в решении данной проблемы является подбор и внедрение эффективных технологий для извлечения таких углеводородных ресурсов.

В настоящее время существует ряд технологий, основанных на применении диоксида углерода в качестве агента воздействия, которые успешно применяются на месторождениях высоковязкой нефти по всему миру.

Данная статья посвящена обзору и анализу эффективности проектов по закачке диоксида углерода на залежах высоковязкой нефти в карбонатных коллекторах. Приводятся сведения о результатах реализации проектов по закачке диоксида углерода на отечественных и зарубежных месторождениях.

Для анализа эффективности проектов были выбраны такие показатели, как отношение объема закачанного газа к объему извлеченной нефти, прирост коэффициента нефтеотдачи и темпа отбора нефти, приходящийся на одну скважину.

Анализ показывает, что отношение объема закачанного диоксида углерода к объему извлеченной нефти может сильно варьироваться в зависимости от геолого-физических характеристик залежей. При этом при циклической закачке $\mathrm{CO}_{2}$ требуется меньшее его количество по сравнению с площадной закачкой. Прирост коэффициента извлечения нефти может достигать 9,14 \% при росте темпов отбора высоковязкой нефти в среднем до 3,8 м $/$ сут/скв.

Stanislav A. Kalinin (Author ID in Scopus: 57194691912) - Leading Engineer of the Department of Analytical Processing of Core Research Results (tel.: +007 3427170166 , e-mail: Stanislav.Kalinin $@$ pnn.lukoil.com).

Oleg A. Morozyuk (Author ID in Scopus: 56006963800) - PhD in Engineering, Head of the Department of Research of Thermal Reservoir Stimulation Methods (tel.: +007342 71701 66, e-mail: Oleg.Morozyuk@pnn.lukoil.com). The contact person for correspondence.

Калинин Станислав Александрович - ведущий инженер отдела аналитической обработки результатов исследования керна (тел.: +007 3427170166 , e-mail: Stanislav.Kalinin@pnn.lukoil.com).

Морозюк Олег Александрович - кандидат технических наук, начальник отдела исследований тепловых методов воздействия на пласт (тел.: +0073427170166 , e-mail: Oleg.Morozyuk@pnn.lukoil.com). Контактное лицо для переписки. 


\section{Introduction}

Considering the outpacing recovery of light crude oil reserves, the problem of intensifying the development of vast highly viscous (more than $30 \mathrm{mPa} \cdot \mathrm{s}$ ) oil resources is becoming increasingly relevant year on year [1]. Their development urges oil and gas producers to implement special technologies and make a considerable investment. Conventional widely used hydrocarbon production methods, when applied to the production of highly viscous oil (HVO), are limited to the recovery factor of $15-20 \%$. Therefore, development of such objects in most cases becomes unprofitable given the existing tax system. Thus, the key challenge in solving this problem is the creation and selection of effective HVO production technologies. Thus far, an impressive extent of laboratory and field research has been carried out to study and test new HVO production methods and their combinations [2-16].

One of the globally unique objects where HVO is produced commercially is the PermoCarboniferous deposit of Usinskoe field. The deposit has an extremely complex structure of the oil-saturated reservoir made up of carbonate rocks. Natural elastic water drive used for development of the main part of the deposit, as well as the geological and physical characteristics of the stratum (formation depth, high oil viscosity, presence of fractures and highly permeable super reservoirs etc.), are the main causes for low values of the oil production rate and oil recovery factor (ORF) [2] which presently amounts to $10 \%$.

A possible option to enhance the development parameters and ORF in the Permo-Carboniferous deposit of Usinskoe field is to use a combination technology for injection of heat transfer media and industrial carbon dioxide $\left(\mathrm{CO}_{2}\right)$ which can be potentially sourced from Usinsky energy centre. Presently, there are several technologies that are based on the use of carbon dioxide as a stimulation agent $[9,17,18]$ and are successfully applied in HVO fields around the world. Among them are fields analogous to the Permo-Carboniferous deposit of Usinskoe field in terms of geological and physical characteristics. The information concerning the results of using the carbon dioxide technologies at these objects will help in preliminary evaluation of the possibility to use them in the conditions of the Permo-Carboniferous deposit. Presented below are the results of pilot projects for HVO production using carbon dioxide and an analysis of the performance indicators of the implemented projects.

Depending on the thermobaric conditions and oil composition, the injection of carbon dioxide into the formation can trigger various displacement conditions: completely miscible, partially miscible and immiscible displacement. For the formation conditions of high-viscosity oil deposits, as a rule, the immiscible displacement is implemented. The main enhanced recovery mechanisms are the viscosity reduction when carbon dioxide dissolves in the formation oil, the oil volume increase (swelling), the manifestation of dissolved gas drive, the production of light and medium oil fractions and their transition into the light (carbon-dioxide) phase, as well as the reduction of surface tension at the reservoir oil $-\mathrm{CO}_{2}$ boundary [19-24].

The first successful project for the immiscible displacement of oil with carbon dioxide was implemented at Ritchie Field (Arkansas, USA) in 1968 [25]. In subsequent decades, along with the US, many other countries around the world implemented projects for the immiscible displacement of oil with carbon dioxide, such as China, Turkey, Trinidad, Malaysia, Hungary, Argentina, Canada, and Brazil. [26]. Figure 1 represents the distribution of the projects for the immiscible displacement of oil with carbon dioxide at the implementation stage across countries.

Figure 1 shows that the majority of the immiscible displacement projects are being or have been implemented in the US. This can be explained by the presence of considerable natural carbon dioxide reserves in the US territory, and a dense pipeline network for liquid $\mathrm{CO}_{2}$ delivery to the place of injection [27]. The US currently remains a leader in the quantity

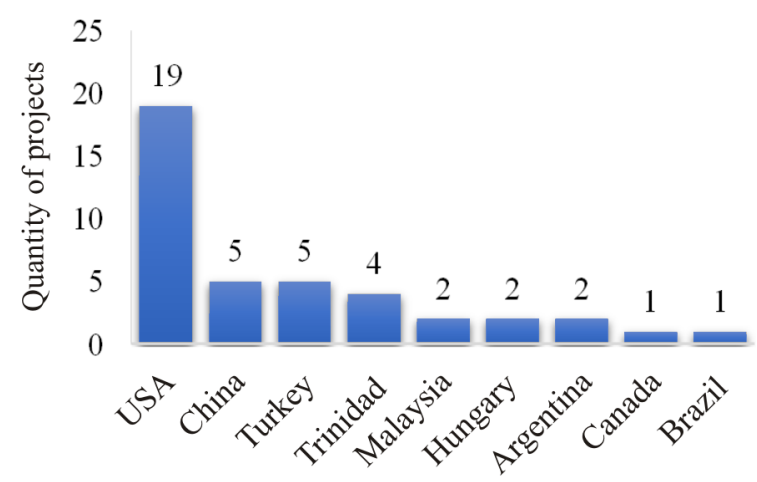

Fig. 1. Distribution of projects for immiscible displacement of oil with carbon dioxide across countries (adapted from [26]) 
of ongoing enhanced oil recovery projects using carbon dioxide injection. As of 2014, 128 projects for $\mathrm{CO}_{2}$ injection are being implemented in the territory of the United States of America, with 88 out of them considered to be successful $[28,29]$.

\section{Foreign experience in using $\mathrm{CO}_{2}$ injection technologies for development of highly viscous oil deposits in carbonate reservoirs}

According to the published data $[26,30]$, only 9 out of 42 projects for the immiscible displacement of oil with carbon dioxide have been implemented in the productive strata made up of carbonate rocks. Six out of them were implemented in the highly viscous or ultra-viscous oil deposits (Table 1). The fields are to a certain extent similar in their geological and physical characteristics to the characteristics of the Permo-Carboniferous deposit of Usinskoe field.

\section{Nagylengel field}

Being the second largest in Hungary in terms of oil reserves, the field has been actively developed in the period from 1951 to 1973 using natural water drive. The oil-saturated formation has a complex geological structure and is divided into 14 blocks. The highly viscous oil reserves are associated with the Upper Cretaceous deposits, comprising organic (rudist, shelly) limestone, and Triassic dolomites with expressed vugginess, karst voids and fracturing of tectonic origin. The reservoir saturated with highly viscous oil manifests high fracture permeability. In 1980 the field was completely waterlogged, the wells were being used with the product water cut levels approximating to $100 \%$.

As a pilot project, the reservoir was injected with carbon dioxide sourced from Budafa deep horizon containing natural gas with high $\mathrm{CO}_{2}$ volume concentration (up to $81 \%$ ).

Before the injection of $\mathrm{CO}_{2}$-saturated natural gas in September 1980, the wells have been operated with the product water cut approximating to $96-100 \%$. Over a period of 4 years, from September 1980 to the end of 1984 , the reservoir has been injected with 96.7 million st. $\mathrm{m}^{3}$ of gas, with incremental production of 40.4 thousand $\mathrm{m}^{3}$ oil. Later, between December 1987 and January 1988, another 3.6 million st. $\mathrm{m}^{3}$ of $\mathrm{CO}_{2}$-saturated natural gas have been injected. In total, the gas injection volume amounted to 100.3 million st. $\mathrm{m}^{3}$. The results of the pilot project have been assessed as successful. The incremental oil production amounted to 05.2 thousand $\mathrm{m}^{3}$, which corresponds to the ORF increment of about $9 \%$. Another result was a significant reduction in the well product water cut.

Table 1

Highly viscous oil deposits in carbonate reservoirs injected with $\mathrm{CO}_{2}$ using immiscible option

\begin{tabular}{|l|c|c|c|c|c|c|}
\hline Country & Field & Object & Stimulation technology & $\begin{array}{c}\text { Implementatio } \\
\mathrm{n} \text { start, year }\end{array}$ & Type of rock & Source \\
\hline Hungary & Nagylengyel & $\begin{array}{c}\text { Blocks VII, } \\
\text { VIII, X.-S. }\end{array}$ & Dispersed injection of $\mathrm{CO}_{2}$ & 1980 & $\begin{array}{c}\text { Organic limestone/ } \\
\text { dolomite }\end{array}$ & Limestone \\
\hline Turkey & Bati Raman & - & $\begin{array}{c}\text { Cyclic injection of } \mathrm{CO}_{2}, \\
\text { Dispersed injection of } \mathrm{CO}_{2} \\
\text { with injection of gels, alternating } \\
\text { injection of water and } \mathrm{CO}_{2} \\
\text { with chemical agents }\end{array}$ & 1986 & [32-36] \\
\hline Turkey & Ikiztepe & Sinan & $\begin{array}{c}\text { Cyclic injection of } \mathrm{CO}_{2}, \\
\text { Dispersed injection of } \mathrm{CO}_{2}\end{array}$ & Until $1997 *$ & Limestone & {$[37]$} \\
\hline Turkey & Bati Kozluka & Alt Sinan & Dispersed injection of $\mathrm{CO}_{2}$ & 2003 & Limestone & {$[30]$} \\
\hline Turkey & Camurlu & Alt Sinan & Cyclic injection of $\mathrm{CO}_{2}$ & 1984 & Limestone & {$[38]$} \\
\hline USA & Halfmoon & Phosphoria & Cyclic injection of $\mathrm{CO}_{2}$ & Until $1992 *$ & $\begin{array}{c}\text { Limestone/ } \\
\text { dolomite }\end{array}$ & {$[39]$} \\
\hline
\end{tabular}

Note : * no exact data, publication date of the paper is specified. 


\section{Bati Raman field}

The field, located in the south-eastern part of Turkey, was discovered in 1981. The productive formation mostly consists of calcareous and chalk rocks. The reservoir type is fractured-porous-vuggy, with strong permeable heterogeneity.

Prior to the beginning of the field development using $\mathrm{CO}_{2}$, the oil recovery factor amounted to about $1.7 \%$ of initial recoverable reserves (the field had been developed using natural drive). The pressure in the oil deposit recovered by the natural drive has dropped. Waterflooding resulted in insignificant oil recovery improvement.

The cyclic injection of carbon dioxide at Bati Raman field has been used in the scope of a pilot project since 1986. Carbon dioxide has been sourced from Dodan gas field $90 \mathrm{~km}$ away [34]. Due to the specific geological structure of the oil deposit, the injected gas, in one instance, exited the near-wellbore area through highly permeable zones and fractures, preventing pressure increase to the desired level. In another instance, $\mathrm{CO}_{2}$ injection in some of the wells resulted in fast growth of pressure at the well bottom due to their low intake capacity, resulting in a pressure drop at the recovery stage, which prevented the production from achieving a profitable level. Eventually, it was decided to abandon the cyclic $\mathrm{CO}_{2}$ injection technology in favour of the dispersed injection, which after 2 years of implementation was used in the entire field.

However, the presence of fracturing and inhomogeneity contributed to the fact that the injected gas forced its way into the production wells, which resulted in a decrease of effectiveness and loss of incremental oil.

To improve the reservoir sweep efficiency in the process of displacement, injection of polymeric gel systems and alternating injection of water and $\mathrm{CO}_{2}$ with added $\mathrm{NaOH}$ in a concentration of $0.5 \%$ wt. were implemented in the field. These measures helped to even the intake profile, improve oil displacement effectiveness and reduce product water cut.

\section{Ikiztepe field}

The field is located in the south-eastern part of Turkey. The productive formation mostly consists of carbonates and, more seldom, of dolomites with irregular vugginess and fracturing. $\mathrm{CO}_{2}$ for the field was sourced from the neighbouring Camurlu field. To improve $\mathrm{CO}_{2}$ purity to $90 \%$ and above, membrane separation was used. [40]

The pilot project was limited to the area of $200 \times 200 \mathrm{~m}$, drilled according to the reverse 5-point system. $\mathrm{CO}_{2}$ was injected into the central injection well; the recovery was performed from the producing wells located in the corners of the area.

Initially, prior to the dispersed $\mathrm{CO}_{2}$ injection, the injection well performed three cycles of cyclic carbon dioxide injection to improve the well intake, with a production of about $146 \mathrm{~m}^{3}$ oil at an injection of 0.195 million st. $\mathrm{m}^{3}$ of $\mathrm{CO}_{2}$.

Based on the analysis of the pilot test, the authors concluded that the reservoir development using $\mathrm{CO}_{2}$ injection with immiscible displacement is a viable technology which is applicable to other similar HVO fields. Notably, the key factor of producing incremental oil is the high solubility of carbon dioxide in oil.

\section{Bati Kozluca field}

The field is located in the south-eastern part of Turkey and was discovered in 1985. The main productive formation of the field, Alt Sinan, consists of carbonate rocks. As a result of geophysical well logging and core analysis, three facies were identified in the field. The upper facies, which is the major source of the produced oil, consists of granular limestone with a porosity of $22-30 \%$ and maximum permeability.

The field development started on the natural drive in 1985 with 41 wells in the stock. The peak production reached the level of 274 t/day in 1987 , followed by a rapid decline due to the following major causes: insufficient reservoir pressure, low reservoir sweep efficiency, high density and viscosity of the oil in reservoir conditions. From 1994 to 2002, the oil production at the field was maintained on the same level.

The dispersed injection of carbon dioxide at the field was started in May 2003 and involved six injection wells. Carbon dioxide was sourced from Camurlu field (the Mus deposit). Over four years of field development using the dispersed injection of $\mathrm{CO}_{2}$, the oil recovery factor grew from 5 to $6.7 \%$ and the producing wells' output doubled. About 230 thousand tons of the incremental oil was 
produced owing to the $\mathrm{CO}_{2}$ injection. The gas-oil ratio amounted to nearly $1000 \mathrm{st} . \mathrm{m}^{3}$ per $1 \mathrm{~m}^{3}$ of the incrementally produced oil.

The performed laboratory tests and computational modelling have shown that only by regulating the process of the dispersed $\mathrm{CO}_{2}$ injection, the oil recovery factor of the field can be improved up to $9 \%$ without additional investment in field infrastructure development.

\section{Camurlu field}

The field is located in the south-eastern part of Turkey. Three productive deposits have been identified at various depths of the field. The upper object Alt Sinan, being the major source of the produced oil, is located in chalk deposits and confined by light-brown limestone. $\mathrm{CO}_{2}$ for the Alt Sinan deposit and Bati Kozluca field is sourced from the lower object Mus. The Alt Sinan deposit exhibits natural fracturing. Vertically and horizontally oriented fractures are distributed randomly.

The production at the field was started in May 1976 with an average daily oil flow rate of $16 \mathrm{~m}^{3} /$ day, typical for most of the wells. Over two years, the average oil flow rate went down to $2.4-3.2 \mathrm{~m}^{3} /$ day/well, with almost no increase in the product water cut. The cumulative oil production as of December 1986 amounted to 110.3 thousand $\mathrm{m}^{3}$. Due to low output of the wells and low recovery factor (less than $1 \%$ ) a pilot project was implemented at the field for cyclic injection of carbon dioxide (Huff and Puff) in two wells, C-11 and $\mathrm{C}-22$. Each well was exposed to three injectionimbibition-recovery cycles. The carbon dioxide injection was performed without any compressor equipment due to the sufficient reservoir pressure in Mus object. The pilot project results are presented in Table 2. The authors of [30] have stated that although the performed well treatments had been unprofitable, the technical findings had been promising.

\section{Halfmoon field}

The field is located in the north-western part of Wyoming, USA. Twenty-seven producing wells and one injection well were used to tap two productive horizons:

a) the upper horizon Phosphoria lies in the Permian deposits and is represented by a carbonate reservoir of fractured-porous type;

b) the lower horizon Tensleep is represented by a terrigenous reservoir with strong fracturing.

The associated petroleum gas contains up to $94 \%$ $\mathrm{CO}_{2}$. Initially, the field was developed with a lowperforming natural water drive.

Table 2

Results of pilot project for injection of carbon dioxide

in cyclic mode at Camurlu field (based on data in [38])

\begin{tabular}{|c|c|c|c|c|c|c|c|c|}
\hline \multirow[b]{2}{*}{ Cycle } & \multicolumn{2}{|c|}{ Injection } & \multirow[b]{2}{*}{$\begin{array}{l}\text { Imbibition } \\
\text { Imbibition } \\
\text { time, days }\end{array}$} & \multicolumn{5}{|c|}{ Recovery } \\
\hline & $\begin{array}{c}\mathrm{CO}_{2} \\
\text { injection } \\
\text { volume, } \\
\text { thousand } \\
\mathrm{m}^{3}\end{array}$ & $\begin{array}{c}\mathrm{CO}_{2} \\
\text { injection } \\
\text { rate, } \\
\text { thousand } \\
\mathrm{m}^{3} / \text { day }\end{array}$ & & $\begin{array}{l}\text { Free-flow } \\
\text { production of oil, } \\
\mathrm{m}^{3}\end{array}$ & Artificial oil lift, $\mathrm{m}^{3}$ & $\begin{array}{l}\text { Cumulative oil } \\
\text { production, } \mathrm{m}^{3}\end{array}$ & $\begin{array}{l}\text { Average oil } \\
\text { flow rate, } \\
\mathrm{m}^{3} / \text { day }\end{array}$ & $\begin{array}{l}\text { Gas-oil ratio }{ }^{*} \text {, st. } \\
\mathrm{m}^{3} / \mathrm{m}^{3}\end{array}$ \\
\hline \multicolumn{9}{|c|}{ Camurlu-11 well } \\
\hline 1 & 299 & 3.99 & 10 & 30.1 & 305 & 335.1 & 1.7 & 892 \\
\hline 2 & 296 & 2.5 & 19 & 71.7 & 346 & 417.7 & 1.5 & 709 \\
\hline 3 & 165 & 18.3 & 20 & 53.8 & 553.3 & 607.1 & 2.6 & 272 \\
\hline Total & 760 & & & & & 1359.9 & & 559 \\
\hline \multicolumn{9}{|c|}{ Camurlu-22 well } \\
\hline 1 & 74.2 & 4.1 & 13 & 15 & 316 & 331 & 2.5 & 224.2 \\
\hline $2^{* *}$ & 277.8 & 4.4 & 12 & 147 & 551 & 698 & 3 & 398.6 \\
\hline 3 & 185.5 & 31.1 & 10 & 99 & 1049 & 1148 & 3.2 & 160.3 \\
\hline Total & 537.7 & & & & & 2176 & & 246.0 \\
\hline \multicolumn{9}{|c|}{ Total for the two wells } \\
\hline & 1297.7 & & & & & 3535.9 & & 367.0 \\
\hline
\end{tabular}

Note: * - determined as a ratio of cumulative $\mathrm{CO}_{2}$ injection volume at standard conditions to cumulative oil production volume; $* *$ - the cycle has been performed after well acidizing in the volume of $19 \mathrm{~m}^{3} 15 \% \mathrm{HCl}$ solution. 
Geological and physical characteristics of carbonate deposits of highly viscous oil exposed to treatment by carbon dioxide injection technology with immiscible displacement

\begin{tabular}{|l|c|c|c|c|c|c|c|}
\hline \multirow{2}{*}{ Characteristic } & \multicolumn{5}{|c|}{ Field/Object } \\
\cline { 2 - 7 } & $\begin{array}{c}\text { Nagylengyel/ } \\
\text { VII, VIII, } \\
\text { X.-S. }\end{array}$ & Bati Raman & $\begin{array}{c}\text { Ikiztepe/ } \\
\text { Sinan }\end{array}$ & $\begin{array}{c}\text { Bati Kozluca/ } \\
\text { Alt Sinan }\end{array}$ & $\begin{array}{c}\text { Camurlu/ } \\
\text { Alt Sinan }\end{array}$ & $\begin{array}{c}\text { Halfmoon/ } \\
\text { Phosphoria }\end{array}$ & $\begin{array}{c}\text { P-C deposit } \\
\text { of Usinskoe } \\
\text { field }\end{array}$ \\
\hline Depth of occurrence, $\mathrm{m}$ & $2200-2800$ & 1300 & 880 & No data & 800 & 1036 & 1350 \\
\hline Oil-saturated thickness, $\mathrm{m}$ & No data & $60-70$ & $13-22$ & 60 & 60 & 12.2 & 48.3 \\
\hline $\begin{array}{l}\text { Initial reservoir temperature, } \\
{ }^{\circ} \mathrm{C}\end{array}$ & $84-124$ & 65.5 & 50 & No data & 47 & $57.0-60.6$ & 23 \\
\hline $\begin{array}{l}\text { Initial reservoir pressure, } \\
\text { MPa }\end{array}$ & No data & 12.4 & 12.7 & No data & 12.0 & $3.1-6.2$ & 12 \\
\hline Matrix porosity, $\%$ & $1-5$ & $14-20$ & $15-23$ & $22-30$ & $11-22$ & 14 & 19 \\
\hline $\begin{array}{l}\text { Reservoir permeability by } \\
\text { core, } \mu \mathrm{m}^{2} / \mathrm{by} \text { hydrodynamic } \\
\text { well test, } \mu \mathrm{m}^{2}\end{array}$ & No data & $0.01-0.10 /$ & $50-400$ & No data & $0.002-0.700$ & 0.017 & $\begin{array}{c}\text { Less than } \\
0.050 / 2\end{array}$ \\
\hline Oil density, $\mathrm{kg} / \mathrm{m}^{3}$ & $947-980$ & $966-1007$ & $979-1044$ & 982 & $938.8-954.4$ & 953 & 933 \\
\hline Oil viscosity, $\mathrm{mPa} \cdot \mathrm{s}$ & $48-138$ & $450-1000$ & 936 & $480-500$ & $415-705$ & 118 & 710 \\
\hline Gas content, $\mathrm{m}^{3} / \mathrm{m}^{3}$ & 2.5 & 3.7 & 17 & 2.2 & $9.8-23.8$ & No data & $17-23$ \\
\hline Saturation $\mathrm{pressure,} \mathrm{MPa}$ & No data & 1.1 & 6.2 & 0.34 & $2-7.9$ & No data & 6.2 \\
\hline
\end{tabular}

The pilot project for carbon dioxide injection in cyclic mode (Huff and Puff) was performed at Morrison 28 well of the upper Phosphoria horizon. The well tapped into a limited area of the formation which helped to avoid losses of the injected $\mathrm{CO}_{2}$ and reach a steady yield at the recovery stage (Table 3 ).

Prior to the carbon dioxide injection, Morrison 28 well operated with an average daily oil flow rate of about $2.4 \mathrm{t} /$ day at a product water cut of about $60 \%$. The carbon dioxide injection stage continued around one month. During this period, the well was injected with about 263 thousand st. $\mathrm{m}^{3}\left(520 \mathrm{t}\right.$ ) $\mathrm{CO}_{2}$. The productive period (when the well oil flow rate after the treatment was above the oil flow rate before the treatment) continued around 2.0-2.5 months. The average daily flow rate grew by 2.2 times - $5.3 \mathrm{t} /$ day, which corresponds to the incremental oil production of $2.9 \mathrm{t} /$ day. The product water cut has decreased significantly; however it returned to the initial level very quickly. Thus, in one cyclic treatment, about 84 tons of the incremental oil were recovered. It is also noted that together with the product, about one fourth (28\%) of the injected
$\mathrm{CO}_{2}$ was recovered. The gas-oil ratio including the recovered injected carbon dioxide amounted to 3131 st. $\mathrm{m}^{3} / \mathrm{t}\left(3285\right.$ st. $\left.\mathrm{m}^{3} / \mathrm{m}^{3}\right)$.

\section{Domestic experience in oil reservoir development technologies using $\mathrm{CO}_{2}$}

Until 1991, the carbon dioxide injection technology in the Russian territory, according to [41], was implemented at five objects located in the territory of Perm Krai, Samara Oblast, and the Republics of Tatarstan and Bashkortostan: Alexandrovskaya area of Tuymazinskoe field, Olkhovskoe, Radaevskoe, Kozlovskoe, Sergeevskoe and Yelabuzhskoe fields. The volume of the geological reserves under development has been estimated at 61 million tons, which amounted to $8 \%$ of the total oil production using enhanced recovery methods [41]. However, all known projects were of pilot scope and were not commercially implemented due to the absence of natural carbon dioxide fields at that time [42].

In 1965, Alexandrovskaya area of Tuymazinskoe field (the Republic of Bashkortostan) became 
the first USSR site for a pilot project using carbon dioxide to enhance the oil recovery and improve the production rates. The area chosen for this work included one injection well and three production wells. Among advantages of the area were its proximity to the $\mathrm{CO}_{2}$ source, degree of depletion with waterflooding and small size (to limit the experiment time).

The injection of carbonated water was started in 1967. The injection of carbon dioxide and water into the reservoir was performed separately to avoid corrosion consequences. Carbon dioxide was injected through the tubing, water - to the annulus of the injection well. After the carbonated water injection, it was planned to inject service water in the volume equal to the oil recovery at the pilot site.

The total volume of the carbonated water injection amounted to two void volumes with carbon dioxide concentration of $2.5 \%$ for injection of the first plug in the amount of one void volume and $2 \%$ - for the second plug of the same volume. Hydrodynamic tests have established that due to the breakthroughs of carbonated water into the producing wells the scope of the experiment was reduced to the area with two wells (3 and 4).

The injection of carbonated water resulted in a reduced product water cut in well No. 3 and stabilized well No. 4. Characteristically, the increase of oil share in the recovered product was simultaneous with the increase of $\mathrm{CO}_{2}$ share in gas and stabilization of produced water desalination.

The results of studying the intake profile of the injection well suggest an increase in the sweep efficiency by thickness by $30 \%$. The well intake improved by $30-40 \%$. In general for the pilot area, as per the assessment of LLC BashNIPIneft, 27.3 thousand tons of the incremental oil was produced, which corresponds to the oil recovery enhancement by $15.6 \%$ from the initial reserves of the area compared to the water injection. Specific carbon dioxide consumption amounted to $1 \mathrm{t}$ per $5.8 \mathrm{t}$ oil. However, according to [43], the effect was obviously overestimated.

In 1979, LLC BashNIPIneft drew up a "Technological scheme for the development of Olkhovskoe field using $\mathrm{CO}_{2}$ " suggesting the injection of carbon dioxide at blocks I, II and III (object Tl + $\mathrm{Bb}+\mathrm{Ml})$. The $\mathrm{CO}_{2}$ transport from the place of production (Berezniki nitrogen and fertilizing plant) to Olkhovskoe field (Perm Krai) had to occur through the $100 \mathrm{~km}$ trunk pipeline using the main pumping station located in the plant's territory. The technological scheme suggested that the agent plug is injected in portions alternated with water at carbon dioxide to water ratio approximately equal to $1.0: 4.4$. The option advised for implementation suggested injecting a $\mathrm{CO}_{2}$ plug in the size of $15 \%$ from the void volume, which was supposed to result in incremental oil production of 4.545 million tons until the end of development, which corresponds to an increase of final oil recovery by $13.3 \%$ from the remaining reserves exposed to stimulation.

In 1989-1991, Olkhovskoe field Visean object was injected with carbon dioxide through 16 injection wells, however, the overall volume amounted to only $1.75 \%$ from the design level. The obtained results suggest that the performed reservoir stimulation was ineffective due to the lesser volume of $\mathrm{CO}_{2}$ injection versus the design value. The injection of carbon dioxide was discontinued due to the absence of necessary equipment and control system.

The injection of carbon dioxide at Radaevskoe field (Samara Oblast) was started in 1984. The implemented project resulted in injecting 787.2 thousand $\mathrm{t}_{2}$, which is 2.6 times less than the design volume. Due to the carbon dioxide injection, by July 1989 the incremental oil production amounted to 218 thousand $t$. A specific effect of the injection was equal to $0.28 \mathrm{t} / \mathrm{t}$. Some problems occurred during the $\mathrm{CO}_{2}$ injection, namely breaking of the pipes used for the carbon dioxide delivery. After multiple breaks, the pipeline became inoperable. This was the main reason for discontinuation of the pilot project in 1988 [44].

In Yelabuga field (the Republic of Tatarstan), the $\mathrm{CO}_{2}$ injection was started in 1987. In the immediate vicinity of the field, at Nizhnekamsk petrochemical plant, a large volume of waste in the form of liquid $\mathrm{CO}_{2}$ was generated after the launch of a new production facility. It was decided to use the gas volume to enhance oil recovery. According to the estimations, an ORF increment had to amount to $8.15 \%, \mathrm{CO}_{2}$ consumption - maximum $3 \mathrm{t}$ per $1 \mathrm{t}$ of the incremental oil. As a result of three years of work, a test injection of $\mathrm{CO}_{2}$ was performed at three injection wells [45]. Total injection volume amounted to 58.3 thousand t. However, significant investment and extended project payback period, as well as the absence of the equipment that would enable continuous operation during the $\mathrm{CO}_{2}$ 
injection, impeded further development of the technology at that time. In 1989 the project was discontinued due to financial reasons [44].

At Sergeevskoe field (the Republic of Bashkortostan), the carbon dioxide injection into the reservoir was implemented in 1984. A specific effect from the stimulation as of July 1989 amounted to $0.23 \mathrm{t} \mathrm{CO}_{2}$ per $1 \mathrm{t}$ of the produced oil. The injected volume amounted to 73.8 thousand t. [44]

There is also brief information concerning the results of using the technology of carbon dioxide injection in Kozlovskoe field (Samara Oblast), where an injection of 110 thousand tonnes of liquid $\mathrm{CO}_{2}$ produced a specific effect of $0.125 \mathrm{t} / \mathrm{t}$ [44].

\section{Technology performance analysis}

The purpose of carbon dioxide injection into the oil-saturated formation is the production of incremental oil and improvement of production rate. Thus, $\mathrm{CO}_{2}$ injection performance can be characterized by the following indicators: ratio of $\mathrm{CO}_{2}$ injection volume to produced oil volume (gas-oil ratio (GOR)), incremental oil production volume and oil recovery rate increase. Technological indicators of the projects for the immiscible displacement of highly viscous oil, implemented at the deposits analogous to the PermoCarboniferous deposit, are presented in Table 4.

The gas-oil ratio is determined by the ratio of the total volume of the carbon dioxide injected into the formation to the entire volume of the produced oil.
The total carbon dioxide injection volume is calculated as the injected $\mathrm{CO}_{2}$ volume less the carbon dioxide share reinjected into the formation. Figure 2 shows the distribution of gas-oil ratio values for the considered fields analogous to the Permo-Carboniferous deposit of Usinskoe field.

Figure 2 suggests that the GOR value widely varies - from 0.367 to 4.784 thousand st. $\mathrm{m}^{3} / \mathrm{m}^{3}$. Average GOR for the fields where dispersed injection of $\mathrm{CO}_{2}$ was used amounts to 2.2 thousand st. $\mathrm{m}^{3} / \mathrm{m}^{3}$. When using cyclic $\mathrm{CO}_{2}$ injection, the GOR is on average lower by more than $30 \%$ compared to the GOR for dispersed injection and amounts to 1.47 thousand st. $\mathrm{m}^{3} / \mathrm{m}^{3}$. On average for all considered projects, it is required to inject 1.84 thousand st. $\mathrm{m}^{3}$ $\mathrm{CO}_{2}$ to recover $1 \mathrm{~m}^{3}$ of highly viscous oil. The lowest displacement performance is manifested by Ikiztepe field (Turkey), where the large volume of gas injection is explained by low mobility of the oil (due to the high viscosity in formation conditions and relatively low permeability of the reservoir). High effectiveness of the treatment with gas is achieved in Bati Raman and Bati Kozluka fields, where the GOR value amounted to 1.78 and 1.34 thousand st. $\mathrm{m}^{3} / \mathrm{m}^{3}$, respectively.

Figure 3 shows the distribution of the incrementally produced oil values achieved by the $\mathrm{CO}_{2}$ injection in analogue fields. In this instance, the incremental oil production shows an increase in the oil recovery factor when using the technology of oil immiscible displacement with carbon dioxide.

Table 4

Performance indicators in implemented projects for injection of carbon dioxide in fields analogous to Permo-Carboniferous deposit of Usinskoe field

\begin{tabular}{|c|c|c|c|c|c|c|}
\hline Field & Injection & Scope & $\begin{array}{c}\text { Oil yield } \\
\text { increment, times }\end{array}$ & $\begin{array}{c}\text { GOR, } \\
\text { st. } \mathrm{m}^{3} / \mathrm{m}^{3}\end{array}$ & $\begin{array}{l}\text { Incremental oil } \\
\text { production, } \%\end{array}$ & $\begin{array}{c}\text { Oil production } \\
\text { rate increment, } \\
\text { t/day/well }\end{array}$ \\
\hline Nagylengyel & Dispersed & Field & No data & 953.4 & 9.14 & 6.2 \\
\hline Bati Raman & Dispersed & Field & 1.6 & 1782 & 6 & 3.7 \\
\hline Ikiztepe & Cyclic & 1 well (injection) & No data & $1295^{*}$ & No data & No data \\
\hline Ikiztepe & Dispersed & $\begin{array}{l}1 \text { injection well, } 4 \\
\text { production wells }\end{array}$ & No data & 4784 & No data & No data \\
\hline Bati Kozluka & Dispersed & Field & 2 & 1342 & 1.7 & No data \\
\hline Camurlu & Cyclic & 2 wells & No data & $367^{*}$ & No data & 1.9 \\
\hline Halfmoon & Cyclic & 1 well & 2.4 & 2740 & No data & 3.4 \\
\hline
\end{tabular}

Note: $*$ - on average for three cycles. 


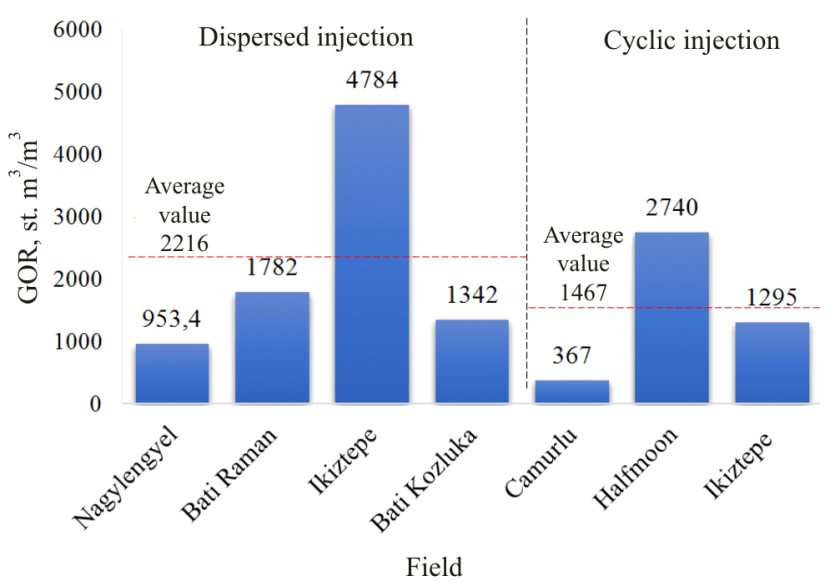

Fig. 2. Gas-oil ratio values for analogue fields

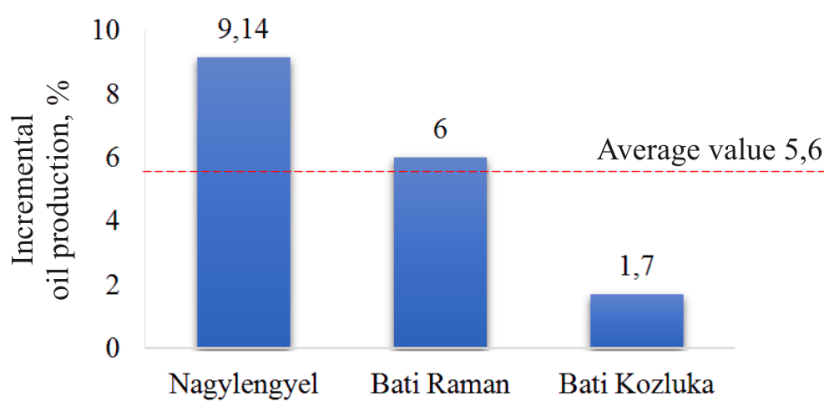

Fig. 3. Distribution of incrementally produced oil values achieved due to $\mathrm{CO}_{2}$ injection at considered analogue fields

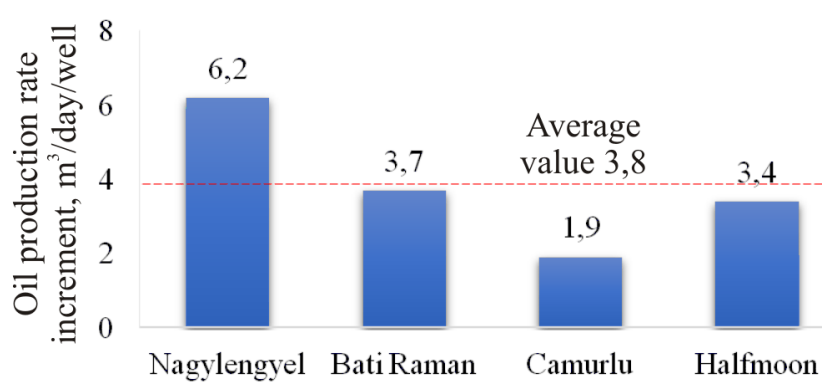

Fig. 4. Additional increment of oil production rate achieved due to $\mathrm{CO}_{2}$ injection at considered analogue fields

An analysis of Figure 3 shows that the incremental oil production varies between 1.7 and $9.14 \%$. The average value amounts to $5.6 \%$. In [33] it is mentioned that for some of the production strata areas in Bati Raman field, the displacement factor increment reaches 9-10\%. The oil recovery increment in Nagylengyel field (Hungary) amounted to $9.14 \%$, which was due to the relatively lower viscosity of formation oil compared to the oil viscosity in other fields and, respectively, higher reservoir sweep efficiency of the displacement.
Due to the varying size and number of producing wells in the deposits developed using the technology of immiscible oil displacement with carbon dioxide, a comparison by this parameter requires that it is made pro rata to the number of producing wells. Figure 4 shows the distribution of additional increment of oil production rate per one well across the considered analogue fields.

Figure 4 also shows that using the immiscible displacement technology can improve the oil recovery rate on average by $3.8 \mathrm{~m}^{3} /$ day/well. For Bati Raman and Camurlu fields, which are very similar to the Permo-Carboniferous deposit of Usinskoe field in terms of geological and physical characteristics, the increment amounted to 3.7 and $1.9 \mathrm{~m}^{3} /$ day/well, respectively.

\section{Conclusions}

1. Presently, there is a significant experience gained in implementation of the technologies for the immiscible displacement of oil with carbon dioxide to enhance oil recovery from highly viscous oil deposits. The literature review shows that the experience of using carbon dioxide for oil recovery enhancement in Russia is virtually absent and is limited to pilot projects which were performed at six fields during the Soviet period starting from the 1960s till late 1980s.

2. Globally there are at least six fields similar in their geological and physical characteristics to the Permo-Carboniferous deposit of Usinskoe field and stimulated, to a various extent, by the technology of immiscible oil displacement with carbon dioxide.

3. The analysis of project performance indicators for the immiscible oil displacement with carbon dioxide suggests that, depending on the geological and physical conditions of the reservoirs, relatively high process indicators can be achieved. For the conditions of deep carbonate formations saturated with highly viscous oil, the recovery factor increment can amount to $1.7-9.14 \%$. An increment of the oil production rate on average is equal to 3.8 tonnes of oil per day per one well. However, due to the strong inhomogeneity and fracturing of carbonaceous deposits, significant volumes of carbon dioxide are necessary. The production of $1 \mathrm{~m}^{3}$ of highly viscous oil requires an average of 1.84 thousand $\mathrm{m}^{3}$ of carbon dioxide. 


\section{References}

1. Moroziuk O.A. Puti povysheniia effektivnosti termoshakhtnoi razrabotki zalezhei anomalno viazkoi nefti: na primere Iaregskogo mestorozhdeniia [Ways to improve the efficiency of thermal mine development of deposits of abnormally viscous oil: the example of the Yarega]. Ph. D. thesis. Ukhta, 2011. $136 \mathrm{p}$.

2. Ruzin L.M., Chuprov I.F., Moroziuk O.A., Durkin S.M. Tekhnologicheskie printsipy razrabotki zalezhei anomalno viazkikh neftei i bitumov [Technological principles for the development of deposits of abnormally viscous oils and bitumen]. Moscow, Izhevsk, Institut kompiuternykh issledovanii, 2015, $480 \mathrm{p}$.

3. Moroziuk O.A., Barkovskii N.N., Kalinin S.A., Bondarenko A.V., Andreev D.V. Eksperimentalnye issledovaniia vytesneniia vysokoviazkoi nefti dioksidom ugleroda iz karbonatnykh porod [Experimental study of heavy oil displacement by carbon dioxide from carbonate rocks]. Geology, Geophysics and Development of Oil and Gas Fields, 2019, no.6, pp.51-56. DOI: 10.30713/2413-5011-2019-6(330)-51-56

4. Ruzin L.M., Moroziuk O.A., Durkin S.M., Kalinin S.A., Skvortsov A.S., Rekhachev P.N., Barkovskii N.N., Iakimov O.I. Laboratornye issledovaniia vliianiia dobavki shchelochi $\mathrm{k}$ zakachivaemomu teplonositeliu na koeffitsient vytesneniia vysokoviazkoi nefti [Laboratory studies of the effect of an alkali addition to the injected heat carrier on the displacement coefficient of high-viscosity oil]. Oilfield engineering, 2017, no.5, pp.14-19.

5. Ruzin L.M., Moroziuk O.A., Durkin S.M., Kalinin S.A., Skvortsov A.S., Putilov I.S., Rekhachev P.N., Barkovskii N.N. Laboratornye issledovaniia vliianiia dobavki rastvoritelia $\mathrm{k}$ zakachivaemomu teplonositeliu na protsess teplovogo vozdeistviia [Laboratory studies of the effect of solvent addition to the injected heat carrier on the heat treatment process]. Oilfield engineering, 2017, no.9, pp.28-34.

6. Durkin S.M., Moroziuk O.A., Kalinin S.A., Ruzin L.M., Menshikova I.N. Obosnovanie optimalnykh rezhimov zakachki teplonositelia dlia povysheniia nefteotdachi Iaregskogo mesto- rozhdeniia na osnove fizicheskogo i matematicheskogo modelirovaniia [Substantiation of the optimal strategies of steam injection for enhanced oil recovery at the Yaregskoye field based on physical and mathematical modeling]. Oil industry, 2018, no.1, pp.58-61. DOI: $10.24887 / 0028-2448-2018-1-58-61$

7. Altunina L.K., Kuvshinov V.A., Kuvshinov I.V., Chertenkov M.V., Ursegov S.O. Pilot tests of new EOR technologies for heavy oil reservoirs. SPE Russian Petroleum Technology Conference, 26-28 October. Moscow, Society of Petroleum Engineers, 2015. DOI: $10.2118 / 176703-\mathrm{MS}$

8. Altunina L.K., Kuvshinov V.A., Kuvshinov I.V., Stasyeva L.A., Chertenkov M.V., Shkrabyuk L.S., Andreev D.V. Physicalchemical and complex EOR/IOR technologies for the Permian-Carboniferous deposit of heavy oil of the Usinskoye oil field. Oil Industry Journal, 2017, no.07, pp.26-29. DOI: 10.24887/0028-2448-2017-7-26-29

9. Alireza Emadi. Enhanced heavy oil recovery by water and carbon dioxide flood: Submitted for the Degree of Doctoral of Philosophy In Petroleum Engineering. Edinburgh, 2012. $372 \mathrm{p}$.

10. Luo P., Erl V., Freitag N., Huang S. Recharacterizing evolving fluid and PVT properties of Weyburn oil- $\mathrm{CO}_{2}$ system. International Journal of Greenhouse Gas Control, 2013, no.16, pp.226-235. DOI: 10.1016/j.ijggc.2013.03.001

11. Bryant D.W., Monger T.G. Multiplecontact phase behavior measurement and application with mixtures of $\mathrm{CO}_{2}$ and highly asphaltic crude. SPE Reservoir Engineering. 1988, vol.3, no. 2, pp. 701-710.

12. Parasiliti Parracello V., Bartosek M., De Simoni M., Mallardo C. Experimental evaluation of $\mathrm{CO}_{2}$ injection in a heavy oil Reservoir // International Petroleum Technology Conference. Bangkok, 7-9 February.

13. Chung F.T.H., Jones R.A., Nguyen H.T. Measurements and correlations of the physical properties of $\mathrm{CO}_{2}-$ heavy crude oil mixtures. SPE Journal, 1988, vol.3, no.3, pp.822-828. DOI: $10.2118 / 15080-P A$ 
14. Lashkarbolooki M., Riazi M., Ayatollahi S. Experimental investigation of dynamic swelling and Bond number of crude oil during carbonated water flooding; Effect of temperature and pressure. Fuel, 2018, no.214, pp.135-143. DOI: 10.1016/j.fuel.2017.11.003

15. Zheng S., Li H., Yang D. Pressure maintenance and improving oil recovery with immiscible $\mathrm{CO}_{2}$ injection in thin heavy oil reservoirs. Journal of Petroleum Science and Engineering, 2013, vol.112, pp.139-152. DOI: 10.1016/j.petrol.2013.10.020

16. Seyyedsar S.M., Farzaneh S.A., Sohrabi M. Experimental investigation of tertiary $\mathrm{CO}_{2}$ injection for enhanced heavy oil recovery. Journal of Natural Gas Science and Engineering, 2016, vol.34, pp.1205-1214. DOI: 10.1016/j.jngse.2016.08.020

17. Iraji B., Shadizadeh S.R., Riazi M. Experimental investigation of $\mathrm{CO}_{2}$ huff and puff in a matrix-fracture system. Fuel, 2015, vol.158, no.15, pp.105-112. DOI: 10.1016/j.fuel.2015.04.069

18. Liu S.C., Sharma M.P., Harris H.G. Steam and $\mathrm{CO}_{2}$ combination flooding of fractured cores: experimental studies. 46th Annual Technical Meeting of The Petroleum Society of CIM in Banff, May 14-17. Alberta, 1995.

19. Lake L.W. Enhanced oil recovery fundamentals. Society of Petroleum Engineers, 1985.

20. Babalian G.A. Primenenie karbonizirovannoi vody dlia uvelicheniia nefteotdachi [The use of carbonated water to increase oil recovery]. Moscow, Nedra, 1976, 144 p.

21. Glazova V.M., Ryzhik V.M. Primenenie dvuokisi ugleroda dlia povysheniia nefteotdachi plastov za rubezhom [The use of carbon dioxide to enhance oil recovery abroad]. Moscow, VNIIOENG, 1986, 45 p.

22. Miller J.S., Jones R.A. A laboratory study to determine physical characteristics of heavy oil after $\mathrm{CO}_{2}$ saturation. SPE/DOE Enhanced Oil Recovery Symposium, 5-8 April, Tulsa: Oklahoma, 1981, pp. 259-268.

23. Orr Jr. F.M., Yu A.D., Lien C.L. Phase behavior of $\mathrm{CO}_{2}$ and crude oil in lowtemperature reservoirs. Society of Petroleum Engineers Journal, 1981, no.4, pp. 480-492.

24. Orr Jr. F.M., Yu A.D., Lien C.L. Multiplecontact phase behavior measurement and application with mixtures of $\mathrm{CO}_{2}$ and highly asphaltic crude. SPE Reservoir Engineering, 1988, no.3, pp.701-710. DOI: 10.2118/14438-PA

25. Khatib A.K., Earlougher R.C., Kantar K. $\mathrm{CO}_{2}$ Injection as an immiscible application for enhanced recovery in heavy oil reservoirs. SPE California Regional Meeting, 25-27 March. Bakersfield, 1981. DOI: 10.2118/9928-MS

26. Zhang N., Wei M., Bai B. Statistical and analytical review of worldwide $\mathrm{CO}_{2}$ immiscible field applications. Fuel, 2018, vol.220, pp.89-100. DOI: $10.1016 /$ j.fuel.2018.01.140

27. Espie T. A new dawn for $\mathrm{CO}_{2}$ EOR. International Petroleum Technology Conference, 21-23 November. Doha, 2005. DOI: 10.2523/IPTC-10935-MS

28. Koottungal L. Survey: miscible $\mathrm{CO}_{2}$ continues to eclipse steam in US EOR production. Oil \& Gas Journal, 2014, vol.112, no.4, pp.78-91.

29. Kuuskraa V., Wallace M. $\mathrm{CO}_{2}$-EOR set for growth as new $\mathrm{CO}_{2}$ supplies emerge. Oil \& Gas Journal, 2014, vol.112, no.4, pp.66-77.

30. Bender S., Yilmaz M. Full-field simulation and optimization study of mature IWAG injection in a heavy oil carbonate reservoir. SPE Improved Oil Recovery Symposium, 12-16 April. Tulsa, 2014. DOI: 10.2118/169117-MS

31. Doleschall S., Szittar A., Udvardi G. Review of the 30 years' experience of the $\mathrm{CO}_{2}$ imported oil recovery projects in Hungary. SPE International Meeting on Petroleum Engineering held in Beijing, 24-27 March. China, 1992. DOI: $10.2118 / 22362-\mathrm{MS}$

32. Babadagli T., Sahin S., Kalfa U., Celebioglu D., Karabakal U., Topguder N.N.S. Development of heavy oil fractured carbonate Bati Raman field: evaluation of steam injection potential and improving ongoing $\mathrm{CO}_{2}$ injection. SPE Annual Technical Conference and Exhibition, 21-24 September. Denver, 2008. DOI: $10.2118 / 115400-\mathrm{MS}$

33. Sahin S., Kalfa U., Celebioglu D. Bati Raman field immiscible $\mathrm{CO}_{2}$ application - status quo and future plans. SPE Reservoir Evaluation \& Engineering, 2008, vol.11, no.4, pp.778-791. DOI: $10.2118 / 106575-P A$

34. Sahin S., Kalfa U., Celebioglu D., Duygu E., Lahna H. A quater century of progress in the application of immiscible EOR project in Bati 
Raman heavy oil field in Turkey. SPE Heavy Oil Conference Canada, 12-14 June. Calgary, 2012. DOI: $10.2118 / 157865-\mathrm{MS}$

35. Sahin S., Kalfa U., Celebioglu D. Unique $\mathrm{CO}_{2}$-injection expierence in the Bati Raman field may lead to a proposal of $\mathrm{EOR} /$ sequestration $\mathrm{CO}_{2}$ network in the Middle East. SPE Economics \& Management, 2012, vol.4, no.1, pp.42-50. DOI: $10.2118 / 139616-\mathrm{PA}$

36. Sahin S., Kalfa U., Uysal S., Kilic H., Lahna H. Design, implementation and early operation results of steam injection pilot in already $\mathrm{CO}_{2}$ flooded deep-heavy oil fractured carbonate reservoir of Bati Raman field, Turkey. SPE Improved Oil Recovery Symposium, 12-16 April. Tulsa, 2014. DOI: $10.2118 / 169035-\mathrm{MS}$

37. Ishii H., Sarma H.K., Ono K., Issever K. A successful immiscible $\mathrm{CO}_{2}$ field pilot in a carbonate heavy oil reservoir in the Ikiztepe Field, Turkey. $9^{\text {th }}$ European Symposium on Improved Oil Recovery, 20-22 October. Hague, 1997. DOI: $10.3997 / 2214-4609.201406800$

38. Gondiken S. Camurlu field immiscible $\mathrm{CO}_{2}$ huff and puff pilot project. Fifth SPE Middle East Oil Show held in Manama, March 7-10. Bahrain. 1987. DOI: 10.2118/15749-MS

39. Olenick S., Schroeder F.A., Haines H.K., Monger-McClure T.G.Cyclic $\mathrm{CO}_{2}$ injection for heavy-oil recovery in halfmoon field: laboratory evaluation and pilot performance. 67th Annual Technical Conference and Exhibition of the Society of Petroleum Engineers held in Washington DC, October 4-7. Washington, 1992. DOI: $10.2118 / 24645-\mathrm{MS}$
40. Dytnerskii Iu.I., Brykov V.P., Kagramanov G.G. Membrannoe razdelenie gazov [Membrane gas separation]. Moscow, 1991, $344 \mathrm{p}$.

41. Krianev D.Iu., Zhdanov S.A. Primenenie metodov uvelicheniia nefteotdachi plastov v Rossii i za rubezhom. Opyt i perspektivy [Use of advanced reservoir recovery methods in Russia and abroad]. Burenie $i$ neft, 2011, no.2, available at: https://burneft.ru/archive/issues/2011-02/8 (accessed 12 May 2019).

42. Cherepovitsyn A.E., Marinia O.A. Metodicheskie podkhody $\mathrm{k}$ ekonomicheskoi otsenke proektov povysheniia nefteotdachi na osnove zakachki $\mathrm{CO}_{2}$ [Methodical approaches to the economical estimation of $\mathrm{CO}_{2}$ - enhanced oil recovery projects]. Zapiski gornogo instituta, 2011, vol.194, pp.344-348.

43. Surguchev M.L. Vtorichnye i tretichnye metody uvelicheniia nefteotdachi plastov [Secondary and tertiary reservoir recovery methods]. Moscow, Nedra, 1985, 308 p.

44. Trukhina O.S., Sintsov I.A. Opyt primeneniia uglekislogo gaza dlia povysheniia nefteotdachi plastov [Experience of carbone dioxide usage for enhanced oil recovery]. Uspekhi sovremennogo estestvoznaniia, 2016, no.3, pp.205-209.

45. Sidorova K.I. Ekonomicheskaia otsenka ispolzovaniia tekhnologii utilizatsii uglekislogo gaza $\mathrm{v}$ neftianykh mestorozhdeniiakh dlia povysheniia nefteotdachi [Economic assessment of the use of carbon dioxide utilization technology in oil fields to enhance oil recovery]. Ph. D. thesis. Saint Petersburg, $2016,155 \mathrm{p}$

\section{Библиографический список}

1. Морозюк О.А. Пути повышения эффективности термошахтной разработки залежей аномально вязкой нефти: на примере Ярегского месторождения: дис. ... канд. техн. наук: 25.00.17. - Ухта, 2011. - 136 с.

2. Технологические принципы разработки залежей аномально вязких нефтей и битумов / Л.М. Рузин, И.Ф. Чупров, О.А. Морозюк, С.М. Дуркин. - Изд. 2-е, перераб. и доп. - М. Ижевск.: Институт компьютерных исследований, 2015. $-480 \mathrm{c}$
3. Экспериментальные исследования вытеснения высоковязкой нефти диоксидом углерода из карбонатных пород / О.А. Морозюк, Н.Н. Барковский, С.А. Калинин, А.В. Бондаренко, Д.В. Андреев // Геология, геофизика и разработка нефтяных и газовых месторождений. - 2019. - № 6. - С. 51-56. DOI: 10.30713/2413-5011-2019-6(330)-51-56

4. Лабораторные исследования влияния добавки щелочи к закачиваемому теплоносителю на коэффициент вытеснения высоковязкой нефти / Л.М. Рузин, О.А. Морозюк, С.М. Дуркин, 
С.А. Калинин, А.С. Скворцов, П.Н. Рехачев, Н.Н. Барковский, О.И. Якимов // Нефтепромысловое дело. - 2017. - №5. - С. 14-19.

5. Лабораторные исследования влияния добавки растворителя к закачиваемому теплоносителю на процесс теплового воздействия / Л.М. Рузин, О.А. Морозюк, С.М. Дуркин, С.А. Калинин, А.С. Скворцов, И.С. Путилов, П.Н. Рехачев, Н.Н. Барковский // Нефтепромысловое дело. - 2017. - № 9. - С. 28-34

6. Обоснование оптимальных режимов закачки теплоносителя для повышения нефтеотдачи Ярегского месторождения на основе физического и математического моделирования / С.М. Дуркин, О.А. Морозюк, С.А. Калинин, Л.М. Рузин, И.Н. Меньшикова // Нефтяное хозяйство. - 2018. - № 1. - С. 58-61. DOI: $10.24887 / 0028-2448-2018-1-58-61$

7. Pilot tests of new EOR technologies for heavy oil reservoirs / L.K. Altunina, V.A. Kuvshinov, I.V. Kuvshinov, M.V. Chertenkov, S.O. Ursegov // SPE Russian Petroleum Technology Conference, 26-28 October, Russia. - M.: Society of Petroleum Engineers, 2015. DOI: 10.2118/176703-MS

8. Physical-chemical and complex EOR/IOR technologies for the Permian-Carboniferous deposit of heavy oil of the Usinskoye oil field / L.K. Altunina, V.A. Kuvshinov, I.V. Kuvshinov, L.A. Stasyeva, M.V. Chertenkov, L.S. Shkrabyuk, D.V. Andreev // Oil Industry Journal. - 2017. - № 07. - C. 26-29. DOI: 10.24887/0028-2448-2017-7-26-29

9. Alireza Emadi. Enhanced heavy oil recovery by water and carbon dioxide flood: Submitted for the Degree of Doctoral of Philosophy In Petroleum Engineering. - Edinburgh, 2012. - 340 p.

10. Recharacterizing evolving fluid and PVT properties of Weyburn oil- $\mathrm{CO}_{2}$ system / P. Luo, V. Erl, N. Freitag, S. Huang // International Journal of Greenhouse Gas Control. - 2013. - № 16. - P. 226-235. DOI: 10.1016/j.ijggc.2013.03.001

11. Bryant D.W., Monger T.G. Multiplecontact phase behavior measurement and application with mixtures of $\mathrm{CO}_{2}$ and highly asphaltic crude // SPE Reservoir Engineering. 1988. - Vol. 3, № 2. - P. 701-710.

12. Experimental evaluation of $\mathrm{CO}_{2}$ injection in a heavy oil reservoir / V. Parasiliti Parracello,
M. Bartosek, M. De Simoni, C. Mallardo // International Petroleum Technology Conference held in Bangkok, 7-9 February.

13. Chung F.T.H., Ray A.J., Hal T.N. Measurements and correlations of the physical properties of $\mathrm{CO}_{2} /$ heavy-crude-oil mixtures // SPE Journal. - 1988. - Vol. 3, № 3. - P. 822-828. DOI: $10.2118 / 15080-P A$

14. Lashkarbolooki M., Riazi M., Ayatollahi S. Experimental investigation of dynamic swelling and Bond number of crude oil during carbonated water flooding; Effect of temperature and pressure // Fuel. - 2018. - № 214. P. 135-143. DOI: 10.1016/j.fuel.2017.11.003

15. Zheng S., Li H., Yang D. Pressure maintenance and improving oil recovery with immiscible $\mathrm{CO}_{2}$ injection in thin heavy oil reservoirs // Journal of Petroleum Science and Engineering. - 2013. - Vol. 112. - P. 139-152. DOI: $10.1016 /$ j.petrol.2013.10.020

16. Seyyedsar S.M., Farzaneh S.A., Sohrabi M. Experimental investigation of tertiary $\mathrm{CO}_{2}$ injection for enhanced heavy oil recovery // Journal of Natural Gas Science and Engineering. - 2016. - Vol. 34. - P. 1205-1214. DOI: $10.1016 /$ j.jngse.2016.08.020

17. Iraji B., Shadizadeh S.R., Riazi M. Experimental investigation of $\mathrm{CO}_{2}$ huff and puff in a matrix-fracture system // Fuel. 2015. - Vol. 158, № 15. - P. 105-112. 10.1016/j.fuel.2015.04.069

18. Liu S.C., Sharma M.P., Harris H.G. Steam and $\mathrm{CO}_{2}$ combination flooding of fractured cores: experimental studies // 46th Annual Technical Meeting of the Petroleum Society of CIM in Banff, May 14-17. Alberta, 1995.

19. Lake L.W., Johns R., Rossen B., Pope G. Fundamentals of enhanced oil recovery // Society of Petroleum Engineers, 2014. $496 \mathrm{p}$.

20. Бабалян Г.А. Применение карбонизированной воды для увеличения нефтеотдачи. М.: Недра, 1976. - 144 с.

21. Глазова В.М., Рыжик В.М. Применение двуокиси углерода для повышения нефтеотдачи пластов за рубежом. - М.: ВНИИОЭНГ, 1986. -45 c.

22. Miller J.S., Jones R.A. A laboratory study to determine physical characteristics of heavy 
oil after $\mathrm{CO} 2$ saturation // SPE/DOE Enhanced Oil Recovery Symposium, 5-8 April. - Tulsa: Oklahoma, 1981. - P. 259-268.

23. Orr Jr. F.M., Yu A.D., Lien C.L. Phase behavior of $\mathrm{CO}_{2}$ and crude oil in low-temperature reservoirs // Society of Petroleum Engineers Journal. - 1981. - № 4. - P. 480-492.

24. Orr Jr. F.M., Yu A.D., Lien C.L. Multiplecontact phase behavior measurement and application with mixtures of $\mathrm{CO}_{2}$ and highly asphaltic crude // SPE Reservoir Engineering. - 1988. - № 3. - P. 701-710. DOI: $10.2118 / 14438-P A$

25. Khatib A.K., Earlougher R.C., Kantar K. $\mathrm{CO}_{2}$ Injection as an immiscible application for enhanced recovery in heavy oil reservoirs // SPE California Regional Meeting, 25-27 March. - Bakersfield, 1981. - P. 461-471. DOI: $10.2118 / 9928-\mathrm{MS}$

26. Zhang N., Wei M., Bai B. Statistical and analytical review of worldwide $\mathrm{CO}_{2}$ immiscible field applications // Fuel. - 2018. - Vol 220. P. 89-100. DOI: 10.1016/j.fuel.2018.01.140

27. Espie T. A new dawn for $\mathrm{CO}_{2}$ EOR // International Petroleum Technology Conference, 21-23 November. - Doha, 2005. DOI: 10.2523/IPTC-10935-MS

28. Koottungal L. Survey: miscible $\mathrm{CO}_{2}$ continues to eclipse steam in US EOR production // Oil \& Gas Journal. - 2014. - Vol. 112, № 4. P. 78-91.

29. Kuuskraa V., Wallace $\mathrm{M}$. $\mathrm{CO}_{2}$-EOR set for growth as new $\mathrm{CO}_{2}$ supplies emerge // Oil \& Gas Journal. - 2014. - Vol. 112, № 4. P. 66-77.

30. Bender S., Yilmaz M. Full-field simulation and optimization study of mature IWAG injection in a heavy oil carbonate reservoir // SPE Improved Oil Recovery Symposium, 12-16 April. - Tulsa, 2014. DOI: $10.2118 / 169117-\mathrm{MS}$

31. Doleschall S., Szittar A., Udvardi G. Review of the 30 years' experience of the $\mathrm{CO}_{2}$ imported oil recovery projects in Hungary // SPE International Meeting on Petroleum Engineering held in Beijing, 24-27 March. - China, 1992. - P. 305-317. DOI: 10.2118/22362-MS

32. Development of heavy oil fractured carbonate Bati Raman field: evaluation of steam injection potential and improving ongoing
$\mathrm{CO}_{2}$ Injection / T. Babadagli, S. Sahin, U. Kalfa, D. Celebioglu, U. Karabakal, N.N.S. Topguder // SPE Annual Technical Conference and Exhibition, 21-24 September. - Denver, 2008. DOI: $10.2118 / 115400-\mathrm{MS}$

33. Sahin S., Kalfa U., Celebioglu D. Bati Raman field immiscible $\mathrm{CO}_{2}$ application - status quo and future plans // SPE Reservoir Evaluation \& Engineering. 2008. - Vol. 11, № 4. - P.778-791. DOI: $10.2118 / 106575-\mathrm{PA}$

34. A quater century of progress in the application of immiscible EOR project in Bati Raman heavy oil field in Turkey / S. Sahin, U. Kalfa, D. Celebioglu, E. Duygu, H. Lahna // SPE Heavy Oil Conference Canada, 12-14 June. Calgary, 2012.

35. Sahin S., Kalfa U., Celebioglu D. Unique $\mathrm{CO}_{2}$-injection expierence in the Bati Raman field may lead to a proposal of EOR/sequestration $\mathrm{CO}_{2}$ network in the Middle East // SPE Economics \& Management. - 2012. - Vol. 4, № 1. - P. 42-50. DOI: $10.2118 / 139616-\mathrm{PA}$

36. Design, implementation and early operation results of steam injection pilot in already $\mathrm{CO}_{2}$ flooded deep-heavy oil fractured carbonate reservoir of Bati Raman field, Turkey / S. Sahin, U. Kalfa, S. Uysal, H. Kilic, H. Lahna // SPE Improved Oil Recovery Symposium, 12-16 April. - Tulsa, 2014. DOI: $10.2118 / 169035-\mathrm{MS}$

37. A successful immiscible $\mathrm{CO}_{2}$ field pilot in a carbonate heavy oil reservoir in the Ikiztepe Field, Turkey / H. Ishii, H.K. Sarma, K. Ono, K. Issever // 9th European Symposium on Improved Oil Recovery, 20-22 October. - Hague, 1997. DOI: $10.3997 / 2214-4609.201406800$

38. Gondiken S. Camurlu field immiscible $\mathrm{CO}_{2}$ huff and puff pilot project // Fifth SPE Middle East Oil Show held in Manama, March 7-10. - Bahrain. 1987. DOI: $10.2118 / 15749-\mathrm{MS}$

39. Cyclic $\mathrm{CO}_{2}$ injection for heavy-oil recovery in halfmoon field: laboratory evaluation and pilot performance / S. Olenick, F.A. Schroeder, H.K. Haines, T.G. MongerMcClure // 67th Annual Technical Conference and Exhibition of the Society of Petroleum Engineers held in Washington DC, 
October 4-7. - Washington, 1992. - P. 271-280. DOI: $10.2118 / 24645-\mathrm{MS}$
40. Дытнерский
Ю.И.,
Брыков
В.П.,

Каграманов Г.Г. Мембранное разделение газов. М., 1991. - $344 \mathrm{c}$.

41. Крянев Д.Ю., Жданов С.А. Применение методов увеличения нефтеотдачи пластов в России и за рубежом. Опыт и перспективы [Электронный ресурс] // Бурение и нефть. 2011. - № 2. - URL: https://burneft.ru/archive/ issues/2011-02/8 (дата обращения: 16.05.2019).

42. Череповицын А.Е., Маринина О.А. Методические подходы к экономической оценке проектов повышения нефтеотдачи на основе закачки $\mathrm{CO}_{2} / /$ Записки Горного института. 2011. - T. 194. - С. 344-348.

43. Сургучев М.Л. Вторичные и третичные методы увеличения нефтеотдачи пластов. - М.: Недра, 1985. - 308 с.

44. Трухина О.С., Синцов И.А. Опыт применения углекислого газа для повышения нефтеотдачи пластов // Успехи современного естествознания. - 2016. - № 3. - С. 205-209.

45. Сидорова К.И. Экономическая оценка использования технологии утилизации углекислого газа в нефтяных месторождениях для повышения нефтеотдачи: дис. ... канд. экон. наук: 08.00.05. - СПб., 2016. - 155 с.

Please cite this article in English as:

Kalinin S.A., Morozyuk O.A. Using carbon dioxide to develop highly viscous oil fields in carbonate reservoirs. Global experience analysis. Perm Journal of Petroleum and Mining Engineering, 2019, vol.19, no.4, pp.373-387. DOI: $10.15593 / 2224-9923 / 2019.4 .6$

Просьба ссылаться на эту статью в русскоязычных источниках следующим образом:

Калинин С.А., Морозюк О.А. Разработка месторождений высоковязкой нефти в карбонатных коллекторах с использованием диоксида углерода. Анализ мирового опыта // Вестник Пермского национального исследовательского политехнического университета. Геология. Нефтегазовое и горное дело. - 2019. - Т.19, №4. - С.373-387. DOI: $10.15593 / 2224-9923 / 2019.4 .6$ 